\title{
A rapid and efficient method for DNA extraction from paraffin wax embedded tissue for PCR amplification
}

\author{
Kevin Morgan, Letty Lam, Noor Kalsheker
}

\begin{abstract}
DNA from archival, formaldehyde fixed, paraffin wax embedded human tissue, suitable for amplification by the polymerase chain reaction (PCR), was obtained using a microwave method based on the capture of DNA by magnetic beads. Fragments of the $\alpha$-1-antitrypsin gene (AAT) and the apolipoprotein $E$ gene (APOE) were amplified successfully from human liver and brain tissue, respectively. This procedure provides a more rapid, simple and efficient method for reproducibly obtaining DNA from preserved tissue that has been kept in storage for up to $\mathbf{3 0}$ years.
\end{abstract}

(f Clin Pathol: Mol Pathol 1996;49:M179-M180)

Keywords: PCR, DNA extraction, paraffin wax sections.

PCR has proven to be a rapid and extremely sensitive method for examining DNA from formaldehyde fixed, paraffin wax embedded tissue ${ }^{1-5}$ Existing methods consist of a deparaffinising step using organic solvents ${ }^{2-4}$ or are microwave based ${ }^{5}$ followed by proteinase digestion $^{13}{ }^{3}$ or use of a chelating agent ${ }^{4}$ prior to obtaining DNA suitable for use as PCR template. These methods are time consuming and involve repeated manipulations. The method we describe is very rapid (takes less than 15 minutes) and as the procedure is carried out in a single tube, the likelihood of cross-contamination is minimised.

\section{Methods}

Human liver samples (kindly provided by Dr P Williams, Department of Gastroenterology, Llandough Hospital, Cardiff) and human brain tissue samples (kindly provided by Professor J Lowe, Department of Pathology, Queen's Medical Centre, Nottingham) were obtained by cutting $20 \mu \mathrm{m}$ thick serial sections from archival paraffin wax embedded blocks. The brain tissue samples had all been collected within the past five years, whereas some of the liver samples had been in storage for up to 30 years. Three sections from each sample were transferred to a sterile $1.5 \mathrm{ml}$ microcentrifuge tube, to which was added $200 \mu \mathrm{l}$ Dynabeads DNA DIRECT (Dynal (UK) Ltd). This product consists of magnetic beads capable of binding DNA suspended in lysis buffer (composition not disclosed by vendor). The tubes were capped, placed in a microwave oven (Sanyo
EM-S150) and irradiated at 80 watts for 10 seconds (split into two 5 second treatments). During this time the samples were monitored closely to ensure that they did not boil over. Following microwave treatment the samples were incubated at room temperature for five minutes. This resulted in a solid paraffin wax ring forming above the beads/lysis buffer mixture and permitted the DNA released from lysed cells to be adsorbed onto the Dynabeads. The DNA was washed twice with $200 \mu \mathrm{l}$ of washing buffer as supplied (proprietary mix of salts in aqueous solution) using a magnetic particle concentrator (Dynal (UK) Ltd). As the paraffin wax pellet was solidly attached to the wall of the microcentrifuge tube above the aqueous layer, it was pierced easily with a yellow pipette tip thereby allowing washing buffer to be added/removed. After the final wash, the DNA/Dynabeads complex was resuspended in $30 \mu \mathrm{l}$ TE buffer $(10 \mathrm{mM}$ Tris- $\mathrm{HCl}$ ( $\mathrm{pH}$ 8.0), $1 \mathrm{mM}$ EDTA) and transferred to a fresh tube. The DNA was eluted from the beads by heating at $65^{\circ} \mathrm{C}$ for five minutes and stored at $4^{\circ} \mathrm{C}$ until use; $5 \mu \mathrm{l}$ of eluted DNA was used per $50 \mu \mathrm{l} \mathrm{PCR}$.

The DNA obtained was used for amplification of a 227 base pair (bp) fragment of the apolipoprotein E (APOE) gene ${ }^{6}$ and a $237 \mathrm{bp}$ fragment of the $\alpha$-1-antitrypsin (AAT) gene. PCRs were carried out in a total volume of 50 $\mu \mathrm{l}$ consisting of $10 \mathrm{mM}$ Tris- $\mathrm{HCl}(\mathrm{pH} \mathrm{9.0),} 50$ $\mathrm{mM} \mathrm{KCl}, 1.5 \mathrm{mM} \mathrm{MgCl}_{2}, 0.1 \%$ Triton X-100, $200 \mu \mathrm{M}$ dNTPs, 25 pmoles of each primer, and 2.5 units of Taq DNA polymerase (Promega, Madison, Wisconsin, USA). The primers for the AAT PCR were 5'AACGTGTCTCTGCTTCTCTC3' and 5'TTGAGGAGCGAGAGGCAGTT3'; those for the APOE PCR were 5'TCCAAGGAGCTGCAGGCGGCGCA3' and 5'ACAGAATTCGCCCCGGCCTGGTACACTGCCA3'. The APOE PCR mix also contained $10 \%$ dimethylsulphoxide. All reactions were overlaid with 20 $\mu \mathrm{l}$ mineral oil. Amplification conditions were 30 seconds at $94^{\circ} \mathrm{C}, 30$ seconds at $60^{\circ} \mathrm{C}$ (AAT PCR) or 30 seconds at $65^{\circ} \mathrm{C}$ (APOE PCR) and one minute at $72^{\circ} \mathrm{C}$ for 35 cycles.

\section{Results and Discussion}

The AAT and APOE products generated from DNA prepared from paraffin wax embedded human liver and brain tissue were analysed ( 5 $\mu \mathrm{l})$ by electrophoresis in $2.5 \%$ agarose gels. The gel was visualised by staining with ethidium bromide and photographed under ultraviolet light (fig 1). A single band of the expected size was obtained in all cases. 


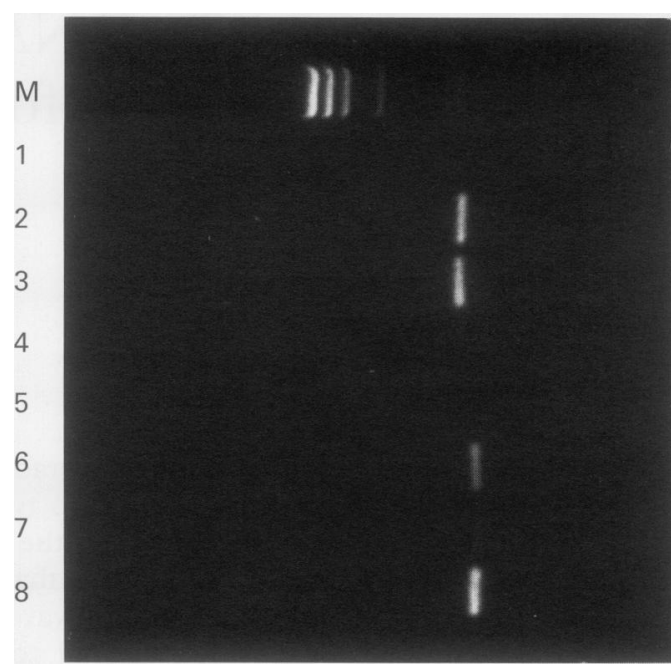

Figure 1 Agarose gel (2.5\%) electrophoresis of PCR products generated from $D N A$ isolated from paraffin wax embedded liver (lanes 1-4) and brain (lanes 5-8) tissue. Lane $M, \Phi \times 174$ DNA markers; lanes 1 and 5, blank controls (no DNA added); lanes 2-4, 237 bp AAT gene fragment amplified from liver tissue; lanes 6-8, $227 \mathrm{bp}$ APOE gene fragment amplified from brain tissue.

Using the method describe herein, it is possible to obtain amplification products reproducibly from DNA isolated from paraffin wax embedded liver and brain tissue. PCR products up to around $240 \mathrm{bp}$ in size can be generated consistently, which in the majority of cases permits further genetic analysis to be performed. We used the $227 \mathrm{bp}$ APOE PCR prod- uct that was amplified from five paraffin wax embedded brain tissue samples for genotyping ${ }^{6}$ and the results obtained matched those determined previously using DNA prepared from frozen $\left(-20^{\circ} \mathrm{C}\right)$ brain tissue, that had been in storage following necropsy, in all five cases (data not shown). As this method is so simple and rapid, it should now be possible to analyse large numbers of preserved samples at the molecular level.

We are very grateful to Nicola Buckley and Roy Edward from Dynal (UK) Ltd for the gift of the Dynabeads DNA DIRECT kit. This work was supported by grants from the Wellcome Trust and Nottingham University Hospitals Trustees.

1 Impraim CC, Saiki RK, Erlich HA, Teplitz RL. Analysis of DNA from formalin-fixed, paraffin embedded tissues by enzymatic amplification and hybridization with sequencespecific oligonucleotides. Biochem Biophys Res Commun specific oligonucleot

2 Shibata DK, Arnheim N, Martin WJ. Detection of human papilloma virus in paraffin-embedded tissue using the polymerase chain reaction. $\mathcal{F} \operatorname{Exp} M e d$ 1988;167:225-30.

3 Wright DK, Manos MM. In: Innis MA, Gelfand DH, Sninsky JJ, WhiteTJ, eds. PCR protocols: a guide to methods and applications. London: Academic Press, 1990:153-8.

4 Chen BF, Clejan S. Rapid preparation of tissue DNA from paraffin-embedded blocks and analysis by polymerase chain reaction. F Histochem Cytochem 1993;41:765-8.

5 Banerjee SK, Makdisi WF, Weston AP, Mitchell SM, Campbell DR. Microwave based DNA extraction from paraffinembedded tissue from PCR amplification. Biotechniques embedded tissue

6 Wenham PR, Price WH, Blandell G. Apolipoprotein E genotyping by one stage PCR (letter). Lancet 1991; 337:1 158-9.

7 Newton CR, Kalsheker N, Graham A, Powell S, Gammack A, Riley J, Markham A. Diagnosis of alpha-1-antitrypsin deficiency by enzymatic amplification of human genomic DNA and direct sequencing of polymerase chain reaction products. Nucleic Acids Res 1988;16:8233-43.
Molecular

Haematology Unit, Department of Haematology, Bristol Royal Infirmary, Bristol BS2 8HW J S Webb G R Standen

Department of Histopathology C M P Collins C P Case

Correspondence to: Dr G R Standen.

\title{
Postmortem diagnosis of Factor V Leiden from paraffin wax embedded tissue
}

\author{
J S Webb, G R Standen, C M P Collins, C P Case
}

\begin{abstract}
Activated protein $\mathrm{C}$ resistance resulting from Factor $V$ Leiden is an important inherited thrombophilia disorder which is found in $3.5 \%$ of people in the UK. The genetic defect can be detected using the PCR and the diagnosis can be made postmortem from paraffin wax embedded tissue. The presence of Factor $V$ Leiden should be sought in all cases of unexplained sudden death resulting from venous thromboembolism.
\end{abstract}

(f Clin Pathol: Mol Pathol 1996;49:M180-M181)

Keywords: Factor V Leiden, thromboembolism, thrombophilia disorder.

Activated protein $\mathrm{C}$ resistance has been recognised recently as an important risk factor predisposing to venous thromboembolism. ${ }^{1}$ The disorder results from a specific missense mutation (G1691A) in exon 10 of the coagula- tion factor $\mathrm{V}$ gene, which is located in the sequence encoding the activated protein $\mathrm{C}$ cleavage site. ${ }^{2}$ Recent studies have shown that the mutant factor Va (Factor V Leiden) is 10 times less susceptible to deactivation by this natural anticoagulant. ${ }^{3}$ Factor V Leiden can be detected by means of the PCR as the nucleotide base change eliminates a cleavage site for the restriction enzyme, Mnll. ${ }^{2} \mathrm{Re}$ cently, we have demonstrated the importance of diagnosing this disorder retrospectively from postmortem paraffin wax embedded tissue.

\section{Case report}

A 24 year old man sustained a soft tissue laceration to the right leg following a road traffic accident. The wound was debrided and sutured and the patient was prescribed diclofenac sodium (Voltarol) as analgesia. One week later, he presented with lower abdominal pain and appendicitis was diagnosed provision- 